\title{
The Impact of Short-Term Study Abroad on Online Learners
}

\author{
Jennifer A. Malerich \\ Arizona State University, USA \\ Universita Cattolica del Sacro Cuore, Italy \\ Email: Jennifer.Malerich@asu.edu \\ Address: Fulton Center 300 E. University Dr. Suite 420 PO Box 877805 Tempe, Arizona 85287-7805 USA
}

\section{Introduction}

The goals of higher education internationalization are increasingly evidenced in institutional mission statements calling for global citizenship and intercultural competencies (Jackson 2008), and in quality discussions centered on developing global-ready graduates, prepared to be successful in increasingly global, interdependant, and technology focused workforce (Carey 2018; Roksa, Arum, and Cook 2016). This support competes with concurrent pressures of rising nationalism and a changing enrollment landscape. In the United States (US), not only did the overall higher education enrollment drop by one million learners between 2012 and 2016, increasing numbers of students are choosing to enroll online (Seaman, Allen, and Seaman 2018). Not just a US phenomenon, access, affordability and convenience are driving higher education enrollment from in-person immersion programs to online programs in markets such as the United Kingdom, India, China and across Africa (African Virtual University n.d.; Allen and Seaman 2017; Coleman 2014; Docebo 2017).

As institutions turn to online learning, it is essential that this growing population is not left out of the benefits of internationalization. Truly comprehensive internationalization requires all students and all courses receive the benefits of actionable strategies (Hudzik 2011). Online learners are a less homogeneous population with regards to age, work experience, family status and educational motivations (Angelino, Williams, and Natvig 2007; Ke and Kwak 2013) than the typical 18-22 year old in-person immersion student population that has been historically studied in higher education at the bachelor degree level (Tinto 1975, 1993). Therefore, effective internationalization strategies may differ for this population. In terms of access to international skill building opportunities, online learners don't come to a physical campus where they can be influenced by traditional internationalization strategies such as interacting with a community of diverse international students and faculty. Little research has been done on how to translate internationalization concepts into effective actions for this specific student population, which represents a growing number of students within undergraduate higher education in the US and around the world.

Increasing numbers of Arizona State University (ASU) students, who were previously studying exclusively online, are choosing to participate in what in the US is a traditional internationalization activity, study abroad. ASU online students participating in study abroad rose from five students in 2009-2010 to over 350 students in 2018-2019, approximately 12 percent of the total study abroad population. Not to be conflated with online or virtual exchange, these students are choosing to leave the online learning environment for an in-person learning environment in another country. Anecdotal evidence (from interviews of returning online study abroad students at ASU) suggests online students who study abroad are seeking discipline specific knowledge and skills as well as an opportunity to interact with fellow learners and faculty in person during their study abroad programs. However, there is a gap in the literature regarding previous systematic research done to assess online learner's motivations for, or professional and academic expectations of, the experience; nor the impact of their participation. 


\section{Research Hypotheses \& Methodology}

Within this context, the hypotheses guiding my research are that, when compared to in-person immersion students who study abroad, online students who study abroad:

- Hypothesis 1: differ across academic and demographic variables.

- Hypothesis 2: have different motivations for, and expectations of, study abroad with regards to their academic and professional goals.

- Hypothesis 3: experience different changes in beliefs, attitudes and values as a result of a study abroad experience.

My research is grounded in both transformative and pragmatic philosophical worldviews. I am approaching this research from a position of wishing to both understand the social and historical contexts of the population studied and influence change. Three theoretical frameworks guide my literature review and study design. Global Learning, a multi-disciplinary approach to problem solving which approaches difference from an asset mentality (Donnelly-Smith 2009; Doscher and Landorf 2018), represents not only ASU's mission of diversity and inclusion but also the intuition's approach to academics. The Theory of Planned behavior suggests that an individual's intention, or the indication of the amount of effort willing to be expended, directly affects how individuals form intentions as well as act (Petzold and Peter 2015; Ramakrishna, Sarkar, and Vijayaraman 2016). Equilintegration (EI) Theory, the foundation of the BEVI standardized assessment, attempts to explain how an individual's unique beliefs, values and life experiences affect how and what they learn (Shealy 2016; Wandschneider et. al 2015).

This mixed methods study incorporates both quantitative data and qualitative data collected through analysis of student academic and demographic variables, surveys, a standardized assessment, interviews and focus groups. The concurrent triangulation approach will be employed to confirm and corroborate findings between the quantitative and qualitative data (Creswell 2013). Participants comprise online (population $=195$ ) and in-person (population $=1,142$ ) students who studied abroad on short-term study abroad programs led by ASU faculty to an international location during the spring 2019 and summer 2019 terms. 
Data Collection Methodology

\begin{tabular}{|c|c|c|c|}
\hline Hypothesis & Data Source & Type & Data Collection Method \\
\hline \multicolumn{5}{|c|}{ Pre-Program Data Collection } \\
\hline 1 & $\begin{array}{c}\text { ASU Office of } \\
\text { Institutional Analysis }\end{array}$ & Quantitative & $\begin{array}{c}\text { Official data housed in University } \\
\text { Student Information System of Record }\end{array}$ \\
\hline 2 & Survey & Quantitative & Qualtrics \\
\hline 3 & Assessment & $\begin{array}{c}\text { Quantitative \& } \\
\text { Qualitative }\end{array}$ & BEVI Assessment \\
\hline 2 & Survey & Quantitative & BeVI Assessment \\
\hline 3 & Assessment & Quantitative \& & Qualitative \\
\hline $2 \& 3$ & Semi-structured & Qualitative & Zoom \\
\hline 23 & Focus Groups & Qualitative & Zoom \\
\hline
\end{tabular}

\section{Implications}

This study will contribute to the existing gap in knowledge regarding the growing number of online students who study abroad. This research will:

- Contribute to research on overall academic and demographic differences between students who study online as compared to in-person.

- Provide knowledge to educators regarding how study abroad experiences change online students' beliefs, attitudes and values.

- Identify motivations and expectations of online students with regards to study abroad and its impact on their personal and professional goals.

- Raise the profile of the online student population within the context of the internationalization plans of higher education institutions.

A complete review of the literature and data collected may also:

- Suggest implications for study abroad program design specifically for online learners.

- Suggest association between study abroad participation and retention/degree completion for online learners 


\section{References}

African Virtual University. n.d. "AVU At a Glance." Accessed January 22, 2018. http://www.avu.org/avuweb/en/avu-at-a-glance/.

Allen, I. Elaine, and Jeff Seaman. 2017. "Digital Learning Compass Distance Education Enrollment Report 2017." $\begin{array}{llll}\text { Accessed } & \text { August } & 017 .\end{array}$ https://onlinelearningconsortium.org/read/digital-learning-compass-distance-education-enrollment-report-2017.

Angelino, Lorraine M, Frankie Keels Williams, and Deborah Natvig. 2007. "Strategies to Engage Online Students and Reduce Attrition Rates." The Journal of Educators Online. 4(2): 1-14. https://files.eric.ed.gov/fulltext/EJ907749.pdf.

Carey, Shelley Johnson. 2018. "From the Editor | Association of American Colleges \& Universities." Peer Review 20(1): 1-3. https://www.aacu.org/peerreview/2018/Winter/editor.

Coleman, Nancy. 2014. “Online Learning: The UK's Scepticism Is Holding It Back.” The Guardian (blog). September 7 ,

https://www.theguardian.com/higher-education-network/blog/2014/sep/07/online-learning-uk-scepticism-holdingit-back.

Creswell, John W. 2013. Research Design: Qualitative, Quantitative, and Mixed Method Approaches. 2nd ed. Thousand Oaks, CA: Sage Publications, 227.

Docebo. 2017. "ELearning Trends for 2018." https://www.docebo.com/elearning-lms-resources/papers-researches/.

Donnelly-Smith, Laura. 2009. "Global Learning through Short-Term Study Abroad | Association of American Colleges \& Universities.” Peer Review 11(4). https://www.aacu.org/peerreview/2009/fall/donnelly-smith.

Doscher, Stephanie, and Hilary Landorf. 2018. "Universal Global Learning, Inclusive Excellence, and Higher Education's Greater Purposes | Association of American Colleges \& Universities." Peer Review 20(1): 4-7. https://www.aacu.org/peerreview/2018/Winter/FIU.

Hudzik, John K. 2011. "Comprehensive Internationalization: From Concept to Action.” Washington, D.C.: NAFSA: Association of International Educators, 44.

Jackson, Jane. 2008. "Globalization, Internationalization, and Short-Term Stays Abroad." International Journal of Intercultural Relations 32(4): 349-58. https://doi.org/10.1016/j.jintrel.2008.04.004.

Ke, Fengfeng, and Dean Kwak. 2013. "Online Learning across Ethnicity and Age: A Study on Learning Interaction Participation, Perception, and Learning Satisfaction." Computers and Education 61(1): 43-51. https://doi.org/10.1016/j.compedu.2012.09.003.

Petzold, Knut, and Tamara Peter. 2015. "The Social Norm to Study Abroad: Determinants and Effects." Higher Education 69(6): 885-900. https://doi.org/10.1007/s10734-014-9811-4.

Ramakrishna, Hindupur, Avijit Sarkar, and Bindiganavale Vijayaraman. 2016. "Factors Affecting the Design of Short-Term Study-Abroad Programs: An Exploratory Study of Two Business Schools." Journal of Teaching in International Business 27(2-3): 124-41. https://doi.org/10.1080/08975930.2016.1219296.

Roksa, Josipa, Richard Arum, and Amanda Cook. 2016. "Defining and Assessing Learning in Higher Education." In Improving Quality in American Higher Education: Learning Outcomes and Assessments for the 21st Century, edited by Richard Arum, Josipa Roksa, and Amanda Cook, 1-36. San Francisco, CA: Jossey-Bass.

Schnusenberg, Oliver, Pieter De Jong, and Lakshmi Goel. 2012. "Predicting Study Abroad Intentions Based on the Theory of Planned Behavior." Decision Sciences Journal of Innovative Education 10(3): 337-361. https://onlinelibrary-wiley-com.ezproxy1.lib.asu.edu/doi/pdf/10.1111/j.1540-4609.2012.00350.x.

Seaman, Julia E, I Elaine Allen, and Jeff Seaman. 2018. "Grade Increase: Tracking Distance Education in the United States.” Accessed January 29, 2018. http://www.onlinelearningsurvey.com/highered.html. 
Shealy, Craig N. 2016. "Beliefs, Events and Values Inventory (BEVI)." In Making Sense of Beliefs and Values :

Theory, Research, and Practice, edited by Craig N. Shealy, 32:113-73. New York, NY: Spring Publishing Company, LLC. https://doi.org/10.1080/02667363.2016.1244925.

Tinto, Vincent. 1975. "Dropout from Higher Education: A Theoretical Synthesis of Recent Research." Review of Educational Research 45(1): 89-125. https://doi.org/10.3102/00346543045001089.

Tino, Vincent. 1993. Leaving College: Rethinking Causes and Cures of Student Attrition. 2nd ed. Chicago, IL: The University of Chicago Press, 296.

Wandschneider, Elizabeth, Dawn T. Pysarchik, Lee G. Sternberger, Wenjuan Ma, Kris Acheson, Brad Baltensperger, and R. T. Good, et al. 2015. "The Forum BEVI Project: Applications and Implications for International, Multicultural, and Transformative Learning." Frontiers: The Interdisciplinary Journal of Study Abroad 25: 150228. https://eric.ed.gov/?id=EJ1071299. 